\title{
Being ethical and bioethical in daily life of primary health care: nurses' perceptions
}

\author{
Ser ético e bioético no quotidiano da atenção primária à saúde: noções do enfermeiro \\ Ser éticos y bioéticos en la vida diaria de la Atención Primaria de Salud: nociones de enfermeras
}

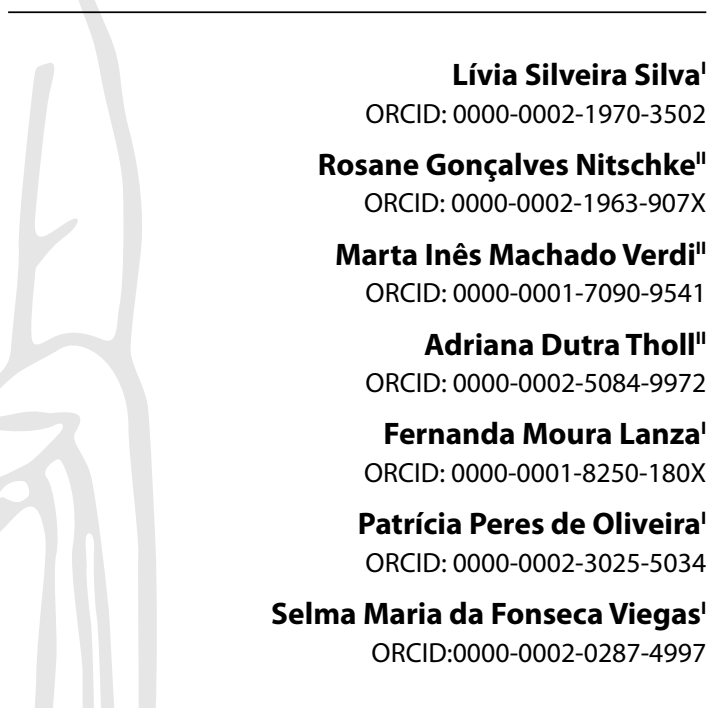

'Universidade Federal de São João del-Rei. Divinópolis, Minas Gerais, Brazil.

"Universidade Federal de Santa Catarina. Florianópolis, Santa Catarina, Brazil.

How to cite this article: Silva LS, Nitschke RG, Verdi MIM, Tholl AD, Lanza FM, Oliveira PP, et al. Being ethical and bioethical in daily life of primary health care: nurses' perceptions. Rev Bras Enferm. 2022;75(3):e20210093. https://doi.org/10.1590/0034-7167-2021-0093

Corresponding author:

Selma Maria da Fonseca Viegas

E-mail: selmaviegas@ufsj.edu.br

EDITOR IN CHIEF: Dulce Barbosa ASSOCIATE EDITOR: Ana Fátima Fernandes

\section{ABSTRACT}

Objectives: to understand the perceptions of ethics and bioethics and how to be ethical and bioethical in daily life of Primary Health Care, from the perspective of nurses. Methods: this is a Holistic-qualitative Multiple Case Study, based on Comprehensive Everyday Sociology, with 54 participants. Results: two subcategories and the category Being ethical and bioethical in daily life of PHC: nurses' perceptions emerged. The ethical and bioethical being permeates a subjective and abstract self, whose fears, anxieties and concerns are intertwined with the human and professional dimensions in daily work and in personal-professional relationship. Ethics and bioethics perceptions emerge from subjectivity, established relationships, lived experiences and daily actions of nurses essential to the profession, professionals and individuals to be cared for. Final Considerations: ethical and bioethical perceptions and attitudes are essential to care, management and organizational actions, health care, and the safety of users and professionals.

Descriptors: Ethics; Bioethics; Ethics, Nursing; Primary Health Care; Activities of Daily Living

\section{RESUMO}

Objetivos: compreender as noções de ética e bioética e como ser ético e bioético no quotidiano da Atenção Primária à Saúde, a partir do olhar do profissional enfermeiro. Métodos: Estudo de Casos Múltiplos Holístico-qualitativo, fundamentado na Sociologia Compreensiva do Quotidiano, com 54 participantes. Resultados: apresenta a categoria Ser ético e bioético no quotidiano da APS: noções do enfermeiro e duas subcategorias. O ser ético e bioético perpassa por um eu subjetivo e abstrato, cujos medos, anseios e preocupações entrelaçam-se às dimensões humanas e profissionais no quotidiano do trabalho e da relação pessoal-profissional. As noções de ética e bioética emergem da subjetividade, das relações estabelecidas, experiências vividas e ações cotidianas dos enfermeiros essenciais à profissão, ao profissional e ao indivíduo a ser cuidado. Considerações Finais: as noções e atitudes éticas e bioéticas são essenciais às ações assistenciais, gerenciais e organizativas, ao cuidado à saúde, e à segurança de usuários e profissionais.

Descritores: Ética; Bioética; Ética em Enfermagem; Atenção Primária à Saúde; Atividades Cotidianas.

\section{RESUMEN}

Objetivo: comprender las nociones de ética y bioética y cómo ser ético y bioético en la vida diaria de la Atención Primaria de Salud, desde la perspectiva del profesional de enfermería. Método: Estudio de caso múltiple holístico-cualitativo, basado en la sociología integral del día a día, con 54 participantes. Resultados: presenta la categoría Ser ético y bioético en la vida diaria de la APS: nociones del enfermero y dos subcategorías. El ser ético y bioético impregna un yo subjetivo y abstracto, cuyos miedos, ansiedades y preocupaciones se entrelazan con las dimensiones humana y profesional en el trabajo diario y en la relación personal-profesional. Las nociones de ética y bioética surgen de la subjetividad, de las relaciones establecidas, de las vivencias y acciones cotidianas de los enfermeros esenciales para la profesión, el profesional y el individuo a cuidar. Consideraciones finales: las nociones y actitudes éticas y bioéticas son fundamentales para el cuidado, la gestión y las acciones organizativas, la atención de la salud y la seguridad de los usuarios y profesionales.

Descriptores: Ética; Bioética; Ética en Enfermería; Atención Primaria de Salud; Actividades Cotidianas. 


\section{INTRODUCTION}

Health care based on the principles of the Unified Health System (SUS - Sistema Único de Saúde) of universal access to services, comprehensiveness and equity, has been a right of Brazilian citizens for more than three decades. During this period, Primary Health Care (PHC) gained prominence, guiding restructuring, transformations and reflections on the formulation of health policies, professional training and daily practices, where the ethical and bioethical dimension of health work makes it imperative ${ }^{(1)}$. In this way of thinking, the skills, actions and effectiveness of the professional exercise of nurses deserve distinction in daily work of PHC.

Nursing is known for the interdisciplinary nature of its knowledge, actions, legislation and ethical precepts, which focus on life, health, assistance and care for users-families-community. Professional practice not only encompasses the practical heteronomy of daily life, but also reason, conscience, subjective, individual values and responsibilities, intrinsic to being as an individual, person and professional ${ }^{(2)}$.

It is also necessary to consider the ethical and bioethical dimensions that involve the professional being as those that are linked to professionals' knowledge, perceptions, emotions and interactions with the world and the dimensions inherent to professional action, which integrate the processes of awareness, empathy, responsibilities, decision-making with autonomy, courage and discernment ${ }^{(3)}$, articulated with the values, obligations and behaviors of the Code of Ethics of Nursing Professionals (CEPE) (4). Understanding that the obligations and duties prescribed in the so-called Codes of Ethics are of the moral order and instrumentalized by deontology; therefore, they list professional duties.

From this perspective, the ethical and bioethical being permeates the personal and professional lives of nurses, their subjective, social, human and collective perceptions inseparable from human character and the experiences, choices and representations that individuals and professionals have a priori. Thus, in addition to technoscientific knowledge, the nursing professional has an ethical, bioethical, civil and criminal identity and commitment, with regard to practice, work, empowerment and professional science ${ }^{(3,5)}$.

A study carried out in Canada described nurses' daily practice as bioethically challenging, a constant personal struggle that involves "awareness of the personal and moral sense of oneself, in accordance with the professional sense ${ }^{\prime \prime(6)}$. On this premise, being ethical and bioethical involves self-perception of oneself and one's subjective abilities and professional self-knowledge in their objective responsibilities, in an approach that goes beyond what is good, to what is also right ${ }^{(6)}$.

It is essential to develop skills, actions and professional reflections in favor of clarifying and alleviating daily difficulties and challenges in $\mathrm{PHC}^{(7)}$. Thus, everyday life can be understood as ways of living and living on a daily basis, manifested in desires, values, beliefs and in the imagination, determining being healthy and falling ill ${ }^{(8)}$.

Thus, the question is: what are the perceptions of ethics and bioethics that underlie the performance of nurses in daily life in $\mathrm{PHC}$ ? How is Being ethical and bioethical in daily life of PHC in the perception of nurses?

\section{OBJECTIVES}

To understand the perceptions of ethics and bioethics and how to be ethical and bioethical in daily life of Primary Health Care, from the perspective of nurses.

\section{METHODS}

\section{Theoretical-methodological framework and type of study}

This is a Holistic-qualitative Multiple Case Study ${ }^{(9)}$, based on the Comprehensive Everyday Sociology theoretical framework ${ }^{(10)}$, originating from a Master's Dissertation. The Comprehensive Everyday Sociology aims to interpret and understand the individual and collective life of people in their sensitive and imaginary reason. "Understanding does not look for cause and effect in the first place, it does not have the chimera of why. Through how, limiting itself to the presentation of things, it strives to understand the internal significance of the observed phenomena"(11).

This study was conducted in accordance with the Consolidated Criteria for Reporting Qualitative Research (COREQ) guidelines.

\section{Study setting}

The universe of study included PHC units in two Brazilian capitals: Belo Horizonte, capital of Minas Gerais State (MG), with $2,375,151$ inhabitants and $78.67 \%$ of population coverage by FHS; and the capital of Santa Catarina State (SC), Florianópolis, with 421,240 inhabitants and $89.53 \%$ of population coverage by FHS.

\section{Methodological procedures}

The research proposed to carry out an individual case study in each capital. The two cases were defined by the study scenarios, configuring a holistic multiple case study ${ }^{(9)}$, with a single unit of analysis: "ethical and bioethical problems experienced by nurses in daily life of PHC". Each case constitutes a complete study, after the analysis of the first case, the second case was replicated with the same unit of analysis, in search of convergent or divergent evidence $^{(9)}$.

A total of 54 nurses working in $\mathrm{PHC}$ in the two Brazilian capitals participated voluntarily in the research. A list of PHC/FHS units was drawn up through a random draw that served as a guide for data collection. In each of the two cases, 15 PHC/FHS units were visited to conduct the interviews, until saturation occurred in the $54^{\text {th }}$ nurse interviewed, thus interrupting data collection. Nurses who work in the PHC units in Belo Horizonte and Florianópolis for a minimum period of six months were included. Nurses away from work or on vacation during the period of data collection were excluded.

According to the criteria of the qualitative research, an exact number of respondents was not determined. The universe of nurses from the 30 health units, which were the research field in the two scenarios of this study, totaled 94. In Florianópolis, of the nurses who were approached (28), 23 participated and five nurses refused to participate in the study; a nurse was on vacation. In the city of Belo Horizonte, considering the nurses who 
were invited to participate (43), there were 31 participants in this study, one nurse refused and eleven nurses were unable to participate in the research due to the high work demand on the days previously scheduled for data collection; two nurses were on vacation and two were on medical certificates. The other nurses, in both cases, were not approached due to data saturation being confirmed in the $54^{\text {th }}$ respondent and data collection ended.

\section{Data source}

As a source of data evidence, open-ended individual interviews and field notes (FN) were used.

An open-ended individual interview with a semi-structured script addressed participnats' characteristics, professional nurses' safety and the ethical and bioethical problems in PHC and was based on the questions: how do you perceive your performance in daily practices in $\mathrm{PHC}$ ? How do you feel about working in the context of $\mathrm{PHC}$ considering your practices and your professional safety to perform the duties of a nurse? What do you understand by Ethics and Bioethics? Have you participated in any training on ethics and bioethics in the context of PHC? If yes, describe to me how it went. What do you understand by ethical and bioethical problems that may permeate the work environment at PHC? In your opinion, what are the biggest ethical and bioethical problems that can be faced in the context of PHC? Do you want to add something about the safety of professional nurses to work in $\mathrm{PHC}$ and the ethical and bioethical problems in PHC? (Open space for the informant). A priori, a pre-test of the interview script was carried out, under the guidance of the responsible researcher.

FN were used for operational purposes of research development, describing peculiar characteristics of the study scenarios, teams, PHC/FHS units and data collection, being analyzed and incorporated into the text of this article.

Ordinance 2436 of September 21, 2017 (PNAB/2017) was established for discussion, with the purpose of analyzing daily experiences according to the attributions of nurses and the attributions common to team members and CEPE.

\section{Data collection and organization}

Data collection in Florianópolis took place in August 2018, in Belo Horizonte in May and June 2019. The interview was conducted by the researcher, conducted according to the participant's availability and in a private room at the health unit. The average duration of the interview was 17 minutes with participants from Belo Horizonte and 12 minutes with those from Florianópolis.

The interview was recorded, validated after it was performed by listening to the digital file by participants, for awareness and freedom of authorization to use the data in its entirety or to have the option of correction. It is noteworthy that the 54 participants consented to the use of their interview data in its entirety. The full transcript of the interviews preserved information reliability.

The collection was ended when data saturation was found in each of the cases in this study, i.e., when a sufficient number of replicated information was obtained, configuring "the literal replication of the data"(9).

\section{Data analysis}

The research data analysis was based on Bardin's framework ${ }^{(12)}$ according to Thematic Content Analysis, in line with the methodological framework of Holistic-Qualitative Multiple Case study ${ }^{(9)}$. Three thematic categories originated: Being ethical and bioethical in daily life of PHC: nurses' perceptions; Safety of professional nurses and ethical and bioethical problems experienced in PHC; Being a nurse in daily life of PHC: doing, learning and living together.

It became pertinent to apprehend the ethical view applied as Critical Hermeneutics based on Kantian philosophy ${ }^{(13)}$ and on Giovanni Berlinguer's view of Daily Bioethics ${ }^{(14)}$ for the interpretation and discussion of the results of this study.

\section{Ethical aspects}

The research was developed considering the guidelines of Resolution 510 of April 7, 2016 and Resolution 466 of the Brazilian National Health Council (Conselho Nacional de Saúde) of December 12, 2012, which consider respect for human dignity and the protection due to participants in scientific research. The Informed Consent Form was signed in duplicate by the participant and the responsible researcher. After approval of the project under the Opinion of the Institutional Review Board of Universidade Federal de São João del-Rei, Center-West Campus and the Opinion of the Institutional Review Board of the Municipal Health Department of Belo Horizonte, data collection began. Entry into the research field took place after authorization from the municipal health secretariats. We used I1, I2, I3... ("I" for interviewee and sequential numbering according to the order in which the interviews were carried out) to guarantee the anonymity of the research participant.

\section{RESULTS}

The presentation of results is configured in a category Being ethical and bioethical in daily life of PHC: nurses' perceptions, which titles this article, and in two subcategories: Being ethical and bioethical and Ethics and Bioethics Perceptions.

The subcategory Being ethical and bioethical reveals the intrinsic principles of Ethics and Bioethics, which permeate nurses' daily lives as a person, individual, subject, and professional.

The ethical and bioethical being is endowed with a subject, professional and human self. In the subject dimension, we go through a subjective and abstract self, whose fears, anxieties and concerns influence their daily lives, the environment and ambience, the personal-professional relationship and work. It articulates the human dimension endowed with conscience, values, wills, duties and responsibilities that intertwine the professional dimension in everyday actions, decision-making Ethics and Bioethics considering the needs of each user/family/ community, considering teamwork:

I think we do beyond what we should. It does things that are not the responsibility of nursing, even taking risks, but it's a way for us to survive. The prescription, like, l leave everything chewed, the doctor just has to stamp the prescription. Like amoxicillin for an infected ear and he doesn't even go there to see the infected ear? 
Does he trust? Like? But it is something that is not ours and that ends up increasing our demand. (112)

Sometimes we have to prioritize service and not do something that is within our competence, because the technical responsibility is ours and, sometimes, you see mistakes happen in the technician's work because you didn't have time to follow up. (144)

The subcategory Ethics and Bioethics Perceptions brings the experiences of doing and knowing in the voice of nurses.

Collectively, the 54 nurses in this research brought Ethics as something abstract and intrinsic to every human being, relating it to perceptions of morality, conscience, experience and values in the biopsychosocial sphere that involves the profession and the professional, actions and individuals to be cared for. But there is also a reference to deontological morals when presenting perceptions focused on the professional code, which is deontological and not ethical:

I understand that you act in a way that is close to what you consider right. So, what do you consider correct and what the institution or that context brings about care? So, the issue of preserving the secrecy, of preserving the integrity of the person, of the issue of character, more in this sense, in relation to human care. (I25)

Ethics is exercising your profession in accordance with your professional code, respecting individuals with all their characteristics. (I28)

Ethics, I understand that it's what I bring from work, what I've learned, different from morality, which is what we learn as a whole, which is the whole, which is life, which are the values. Ethics is what the university helped me to form, which I see on a daily basis how much it impacts on the lives of others: a bad speech, something badly written or badly registered. So, I understand Ethics as this moment, which is inherent to the human being, for us to live in a community, especially in the professional environment, so it is super necessary, isn't it? Because morality will say what I should or shouldn't, like that, but it's more linked to values. Ethics is what must be done, what is in my bylaws, in my code of ethics. (138)

Referring to Bioethics, nurses brought it as ethics applied to life, which involves the basic, decision-making, borderline aspects, life insurance and health of individuals and families:

Bioethics would be applied to life, wouldn't it? Bioethics is everything we do in health that involves decision-making aspects that can harm someone else, especially that the person can choose, isn't it? So, you have the ethics of exposing all the possibilities of a treatment for a patient. (I1)

And Bioethics is within what we can or cannot do, within our capacity, just like in the case of nurses, I have a limit, right? To be done within what I can, what I'm competent to do it. (I24)

Bioethics is the relationship of scientific knowledge with ethics, of its health-related problems, together with professional ethics. (I31)

Bioethics, I think is more linked to life, isn't it? To what belongs to the human being, which brings us so many questions today. Today, we may not be able to listen to the patients qualified, I have no place to see this patient at the right time, in the right place, it's all with a limited time. Today, we deal with data a lot, but at the same time it's a human being, so I need to have a high number, 'more' is something more palpable, something more real, so I think Bioethics passes through there. (I38)

It should be noted that the perceptions of ethics and bioethics assumed by nurses are similar in both scenarios. Of the 54 nurses interviewed, five had difficulties in explaining about Ethics and 14 nurses about Bioethics.

The research also revealed that the nurses in this study had contact with ethical and bioethical contents in the early years of graduation, even so, with a thematic focus in the hospital area:

During graduation, there was one or another course where there were lectures in this regard. After graduation, no. When I participated, there were two courses, I remember that I took this topic, mainly related to euthanasia/dysthanasia, because in graduation, itends up having a greater hospital focus, for example, a four-hourclass, within a course larger than it took all week [...] because it's something that really isn't worked on, we see the legislation at the university as something very boring and unrealistic, something very theoretical. And now, after graduating, we experience this reality, so bringing it back, rereading, re-discussing would be a more favorable moment now. (I1)

When I started college, that's why I don't think I know how to talk about it. I remember that I had taken a course on Ethics and Bioethics, but it was at university, right at the beginning and then never again. It's a topic I honestly don't know. (113)

Of the 54 nurses, only 10 had any contact with the topics Ethics and Bioethics after graduation:

Ah! I've already participated [...] so, it wasn't a training session, the lecture was about something else, but there was a very interesting introduction on Ethics and Bioethics, showing: nowadays, on your cell phone it's common for you to take a picture. If you take a picture of the patient and you are in the Health Unit, this is very dangerous. So, this was addressed in that training, but it wasn't a specific training about it. (14)

A long time ago, I remember it was something that talked about how to deal with life. It is the process that the professional has to deal with life respecting the principles of the whole being. It was offered by the state or the city, I don't remember well. (I44)

The nurses interviewed also emphasize the importance and need for discussion, training, lectures and qualifications that address Ethics and Bioethics in PHC:

Discussions about ethics in Primary Care are very outdated and would be a very important topic for us to work on, because doubts always arise [...]. (11)

He never had a training that talked about Ethics and Bioethics. It should have, because we realize that there really are some problems with professional secrecy, especially with the team. (E9)

In daily work of PHC, the I nurse, subject and human, joins the professional ethos for individual and collective reasons capable of externalizing an action and an act. In this way, it is from the singularities, 
meanings, perceptions, experiences and experiences that nurses configure perceptions of ethical being, Ethics and Bioethics (FN).

Figure 1 presents the summary of the results of Being ethical and bioethical in daily life of PHC.

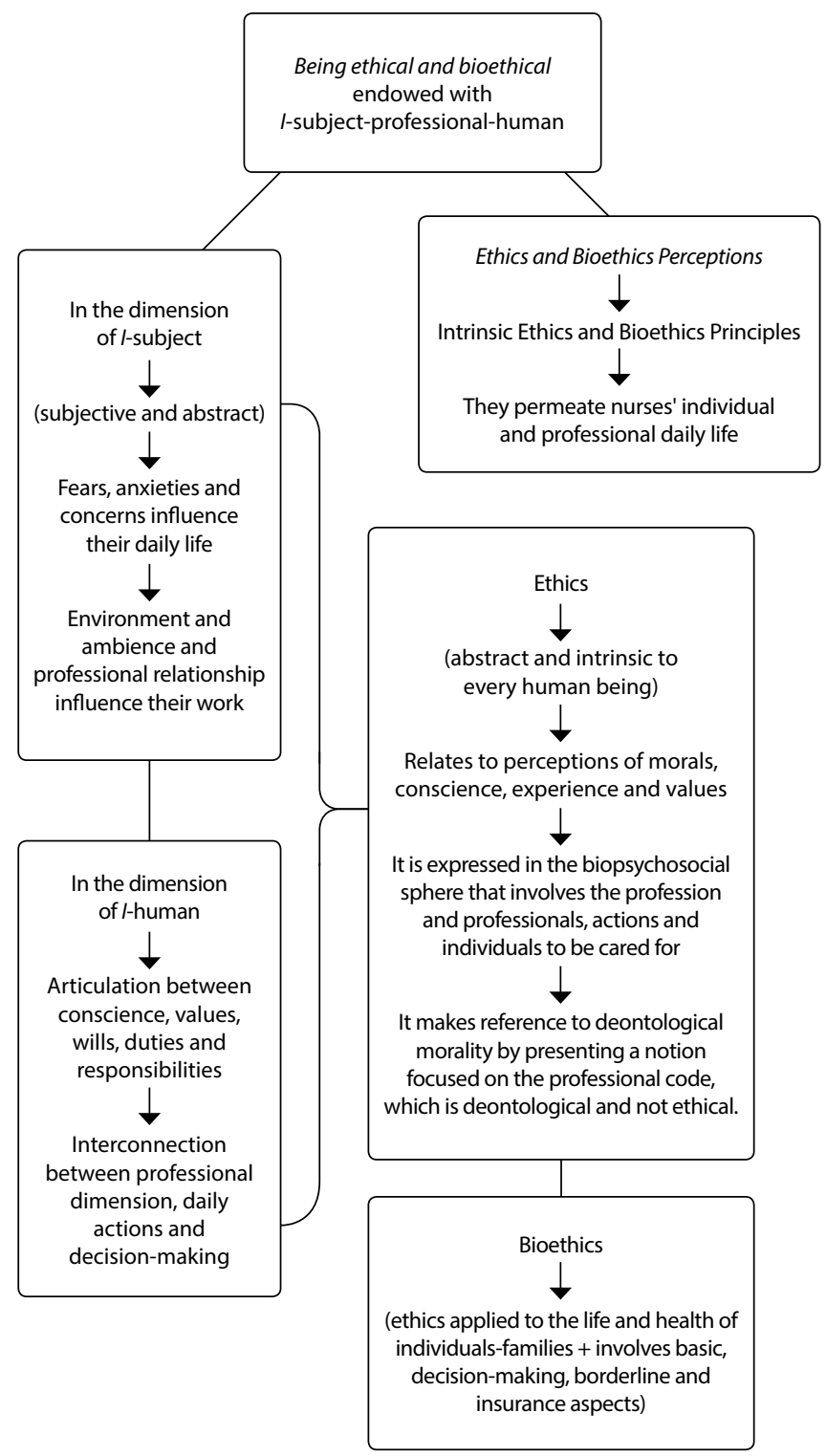

Figure 1- Being ethical and bioethical in daily life of Primary Health Care

Regarding the study participants, the average age among them was 41 years old; $93 \%$ were female; the average time of practice as a nurse was 16 years; $33 \%$ of participants work at Traditional PHC, with an average of 6 years of experience; $67 \%$ work at FHS, with an average of 7 years of experience; $63 \%$ of participants graduated from public institutions; $89 \%$ of nurses had some type of specialization, $56 \%$ in family health, $31 \%$ in public health, $10 \%$ in health management, $8 \%$ in nursing in obstetrics; $8 \%$ have a masters, among others.

\section{DISCUSSION}

By acting, managing, educating and caring, nurses in daily life of PHC, they become protagonists of this entire process. By dealing with various situations, nurses need to take and adopt responsible, honest and legal conduct and conduct, in addition to being aware of the sensitive, subjective, valuable and cultural aspects that involve the production and care relationships considering user-professional-management-community ${ }^{(15)}$. Thus, being ethical and bioethical in daily life of PHC involves the subjective and intrinsic issues of each human being, and the respect-fulfillment of practical issues focused on nurses' care and professional action, outlined by the Brazilian National Policy on Primary Care (PNAB - Política Nacional de Atenção Básica) ${ }^{(16)}$ and by the Code of Ethics for Nursing Professionals ${ }^{(4)}$.

The PNAB/2017 and CEPE are configured as deontological instruments of nursing ${ }^{(2)}$; however, this study showed that even with these instruments, which guide and protect, it is not uncommon for nurses to go beyond what is determined as their attributions ${ }^{(17)}$. This leads us to a bioethically worrying situation, where on the one hand we have a code full of rights, duties, prohibitions and punishments ${ }^{(4)}$, and on the other, a professional surrounded by the need to act in a daily life marked by high spontaneous and repressed demand, in addition to work overload, professional exhaustion, ethical and bioethical problems, tensions and conflicts ${ }^{(18)}$. The ethical and bioethical excellence of care and assistance can only be guaranteed if the ethical and bioethical needs of nurses are met first ${ }^{(19)}$.

Accountability is fundamental for the effectiveness of $\mathrm{PHC}$ as the preferred contact and gateway to the care network, according to the demands and needs of the population ${ }^{(16)}$. There is a report in this study that nurses do beyond what they should be risking, referring to the prescription of medications. Among nurses'specific attributions, PNAB/2017 brings "prescribe medications according to protocols, clinical and therapeutic guidelines, or other technical regulations established by the federal, state, municipal or Federal District manager, subject to the legal provisions of the profes-

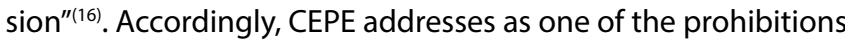
the "prescribing medications that are not established in public health programs and/or routine approved in a health institution, except in emergency situations"(4).

This study showed that nurses are exposed to a characteristic and demanding day-to-day work, strongly influenced by the biologistic model where, often, the immeasurable and impalpable conceptions of their own character meet professional difficulties, distancing them from their ethical and bioethical being ${ }^{(20)}$. Therefore, it is clear that this ethical and bioethical being is built from the fundamentals, conceptions and attributes essential to nursing, such as human dignity, integrality, altruism and justice, which move in balance with the subject, with duty and with acting professionally, guided by principles and values centered on respect for people's lives, dignity and individuality ${ }^{(19-21)}$.

Thus, in general terms, we can also say that there is the being as a person, individual or subject who is polysemic and human, based on a biological, subjective, objective and social conscience and identity achieved through their experiences or experiences in society, still able to define their conduct and position in the face of different contexts, knowledge, and duties ${ }^{(5)}$.

The practice of the profession must be done with "justice, commitment, fairness, resoluteness, dignity, competence, responsibility, honesty and loyalty"(4). Professional/user/family 
relationships must be based on law, solidarity and respect for human dignity and diversities.

As pointed out in this study, exercising the profession in accordance with the professional code refers to deontological morality, duty and obligation. According to Kant ${ }^{(22)}$,"an action performed out of duty has its moral value, not in the purpose that it is intended to achieve, but in the maxim that determines it; it does not depend, therefore, on the reality of the object of the action, but only on the principle of will according to which the action, abstracting from all objects of the faculty of desiring, was practiced".

It is in this way that

"morality, in its principle, rests on a logic of must-be by privileging abstract, eternal values, applicable everywhere and at all times. It is supposed to consider, in a universal way, what is fair. And, precisely, it was in the name of timeless and somewhat disembodied justice that it was established within the scope of national legislation [...] Ethics, in turn, is content with the jute-milieu, the correctness, the balance. From rooting in a given place, it ends up contributing to the power-to-be $e^{(23)}$.

In Kantian philosophy, the ethical being is free, but conscious, capable of taking responsibility for personal, individual or collective and professional actions in the face of pluralities of life and society. Surrounded by its own experiences, interactions and knowledge, it is text and texture in line with its social nature ${ }^{(13,22)}$.

The bioethical being is rational, emotional and human in all ways of dealing with and relating to the internal and external worlds. Subject to new discoveries, it values dialogues, reflections and learning enveloped by the values of biology, biography and the complexities of human identity ${ }^{(14)}$.

For Maffesolian Sociology ${ }^{(10)}$, there is no subject as a conscious and free being, but rather an individual in rational times, or a person in emotional times formed from a unique, expressive and sensory context, which changes through its own history and culture, determined by archetypes of collective unconscious ${ }^{(11)}$.

Despite these interpretations, Ethics and Bioethics contents were included in the field of training, research and practice of nurses, in order to be part not only of the curriculum, but also the identity of these professionals, in order to improve and educate the subject, guide professionals with wisdom and responsibility to work carried out with the precepts of good and safe practices, respecting human dignity ${ }^{(24-25)}$.

Despite the multidisciplinary breadth of the topic at hand, the participants in this study revealed that contact with the contents on Ethics and Bioethics are restricted to the initial years of graduation, with a more hospital and incipient focus for $\mathrm{PHC}$. This incipient approach harms nurses in the identification, delimitation and resolution of ethical and bioethical problems and conflicts existing in $\mathrm{PHC}$, highlighting the growing need for tools such as permanent and continuing education, training, spaces for discussion, among others ${ }^{(26)}$.

To ensure the user universal, equitable and orderly access to SUS health actions and services, PNAB/2017 describes the need to develop technical mechanisms and organizational strategies for workforce qualification for health management and care, to encourage and enable training, permanent and continuing education of professionals ${ }^{(16)}$. CEPE describes as a professional's right to "improve their technical-scientific, ethical-political, socio-educational, historical and cultural knowledge that support professional practice"(4).

Furthermore, national ${ }^{(27-28)}$ and international ${ }^{(19,29-30)}$ studies reveal the continuous and epistemological teaching of Ethics and Bioethics as the best way to answer, deliberate and analyze deeply, critically and argumentatively the ethical and bioethical problems, considering, above all, the moral conduct and the ethical-professional obligations.

It is also noticed that there is a place for ethical and bioethical training influenced by abstraction, connotation, trajectory and teaching during the undergraduate years, at the same time that there is an ethical and bioethical place that permeates the unconscious of the human psyche of each one, an intelligible, non-transferable and inseparable ethics and bioethics to each subject, who, through their own senses, values and knowledge, explore and experience their own perceptions ${ }^{(31)}$.

The ethical and bioethical being goes through stages that go beyond floating principles and rules to philosophy and morality. The ethical and bioethical being is dedicated to daily issues of people's lives and experiences, issues of character and culture that conjure criticism, advice and possibilities about what is desired, what should be done and what can or cannot be done ${ }^{(14)}$.

There are several ethical and bioethical perceptions that meet the social and cultural context where participants in this study are. These perceptions were similar in both scenarios when passing through the individual field of right and wrong, good or bad, justice and morals and through the collective field of interactions, behaviors and professional conducts of acting, living, thinking and relating to oneself, to the teammate and to the user-family-community.

In this way, we are all interpreters and, therefore, we should not close the analysis of experiences lived in concepts and maximum forms, after all, knowledge is substantial, dynamic, variable, interdependent, multiple, innovative and modifiable over time and in the moment in which is situated ${ }^{(11,32-33)}$.

Therefore, it is through the subjectivities, experiences and experiences of nurses in $\mathrm{PHC}$, which mean and re-signify in everyday life, that the notions of ethics and bioethics are materialized. Thus, nurses build their notions and the collective, to do, think, and act ethically and bioethically, through the demanded problems and the needs of each one of users/family, teamwork, behaviors, feelings.

Here, precisely, is wisdom, which leads to an expanded conception of reality. Plural, polysemic reality. Absolute reality. That of experience and collective living. Experience and experience that are not limited to a distant ideal, but that weave, in an endless intertwining, all the affections, emotions, passions, constitutive of daily life, in order to build the social and natural fabric shared in common ${ }^{(34)}$.

Experiences that need to be ethical and bioethical when caring for users and interrelating in daily life of PHC.

\section{Study limitations}

The intentional sampling of 54 nurses participating in the research was a limitation; however, in multiple case studies with data saturation by literal replication ${ }^{(9)}$, it can be representative in populations and scenarios with similar conditions. Data collection 
was hampered by nurses' workload, which prevented or made them postpone the interview, even with the appointment of the interview in advance, according to their availability.

\section{Contributions to nursing}

It is noteworthy that understanding the notions of ethics and bioethics and how to be ethical and bioethical in $\mathrm{PHC}$ is an absolute necessity, considering that for most nurses, contact with ethical and bioethical contents happens in the early years of graduation, with thematic focus in the hospital area. Moreover, it allows managers and competent bodies to pay attention to emerging needs of support, infrastructure and permanent education for professional safety.

\section{FINAL CONSIDERATIONS}

Ethics match possibilities for reflection on moral values and the values of life. Nurses' perceptions of ethics and bioethics emerge from subjectivity, lived experiences, interactions and daily actions considering these values. Daily life is diverse and dynamic and nurses (re)signify their perceptions that come from conscience, reason, nature and morality formed from the subjective self as a person, individual and human subject, and from the professional identity from the fundamentals and essential attributes to nursing as well as reflective, dialogic, decision-making processes that surround health practice.

It can also be inferred that these notions nourished with meanings express essential ethical reflection for the care, management and organizational actions of institutions and health care, as well as for the safety of users and professionals.

\section{FUNDING}

This research was funded by a grant from the Stricto Sensu Graduate Incentive Program (PIPG) at UFSJ. It was also financed by a scientific initiation scholarship by Public Notice 009/2017 PIBIC/FAPEMIG (Minas Gerais State Research Support Foundation - Fundação de Amparo à Pesquisa do Estado de Minas Gerais).

\section{REFERENCES}

1. Viacava F, Oliveira RAD, Carvalho CC, Laguardia J, Bellido JG. SUS: supply, access to and use of health services over the last 30 years. Ciênc Saúde Colet. 2018;23(6):1751-62. https://doi.org/10.1590/1413-81232018236.06022018

2. Silva TN, Freire MEM, Vasconcelos MF, Silva Jr SV, Silva WJC, Araújo PS, Eloy AVA. Deontological aspects of the nursing profession: understanding the code of ethics. Rev Bras Enferm. 2018;71(1):3-10. https://doi.org/10.1590/0034-7167-2016-0565

3. Freitas GF, Oguisso T, Fernandes MFP. Fundamentos éticos e morais na prática de enfermagem. Enferm Foco. 2010;1(3):104-8. https://doi. org/10.21675/2357-707X.2010.v1.n3.37

4. Conselho Federal de Enfermagem (COFEN). Resolução COFEN n 564/2017. Aprova o novo Código de Ética dos Profissionais de Enfermagem. Available from: http://www.cofen.gov.br/resolucao-cofen-no-5642017_59145.html

5. Castro GJM, Costa ML. A Invenção do sujeito. Psicol Ciênc Prof. 2018;38(2):391-402. https://doi.org/10.1590/1982-3703003012017

6. Lamb C, Mould YB, Evans M, Wong CA, Kirkwood KW. Conscientious objection and nurses: results of an interpretive phenomenological study. Nurs Ethics. 2019;26(5):1337-49. https://doi.org/10.1177/0969733018763996

7. Schaefer R, Junges JR. The construction of ethical competence in the perception of primary care nurses. Rev Esc Enferm USP. 2014;48(2):329-34. https://doi.org/10.1590/S0080-623420140000200019

8. Nistchke RG, Tholl AD, Potrich T, Silva KM, Michelin SR, Laureano DD. Contributions of Michel Maffesoli's thinking to research in nursing and health. Texto Contexto Enferm. 2017;26(4):e3230017. https://doi.org/10.1590/0104-07072017003230017

9. Yin RK. Estudo de Caso: Planejamento e Métodos. Porto Alegre: Bookman; 2015. 320 p.

10. Maffesoli M. O conhecimento comum: introdução à sociologia compreensiva. Porto Alegre: Sulina; 2010. 295 p.

11. Maffesoli M. Elogio da razão sensível. Petrópolis: Vozes; 2008. 207 p.

12. Bardin L. Análise de conteúdo. São Paulo: Edições 70; 2011. 229 p.

13. Kant I. Crítica da razão pura. Lisboa: Fundação Calouste Gulbenkian; 2001.680 p.

14. Berlinguer G. Bioética Cotidiana. Brasília: Editora UnB; 2015. 288 p.

15. Santos RMM, Couto TA, Yarid SD. Aspectos éticos e bioéticos encontrados na Atenção Primária à Saúde. Rev Saúde Com. 2018;14(2):1163-72. https://doi.org/10.22481/rsc.v14i2.4035

16. Ministério da Saúde (BR). Secretaria de Atenção à Saúde. Departamento de Atenção Básica. Portaria № 2.436 de 21 de setembro de 2017 [Internet]. Brasília: Ministério da Saúde; 2017[cited 2020 Jul 10]. Available from: http://bvsms.saude.gov.br/bvs/saudelegis/gm/2017/ prt2436_22_09_2017.html

17. Barbosa ML, Rodrigues HNS, Celino SDM, Costa GMC. Nursing professionals' knowledge about the ethics code that governs the profession. Rev Baiana Enferm. 2017;31(4):e21978. https://doi.org/10.18471/rbe.v31i4.21978

18. Silva FG, Silva EG, Delfino VDFR, Pereira GRM. A ética e a moral na assistência de enfermagem. Rev Includere [Internet] 2017 [cited 2020 Jul 10];3(1):307-15. Available from: https://periodicos.ufersa.edu.br/index.php/includere/article/view/7381

19. Schmidt BJ, McArthur EC. Professional nursing values: a concept analysis. Nurs Forum. 2018;53(1):69-75. https://doi.org/10.1111/nuf.12211 
20. Carvalho AM, Carvalho PM, Souza G, Resende MA, Pereira SS, Carvalho AS. A conduta ética dos profissionais de enfermagem: uma revisão. Rev Eletr Acervo Saúde. 2018;(Sup.11):S1709-16. https://doi.org/10.25248/REAS174_2018

21. Santos MAM, Santos FN. Bioética: íntimo de cada ser humano. Ciênc Biol Saúde [Internet]. 2016 [cited 2020 Jul 10];3(3):35-56. Available from: https://periodicos.set.edu.br/index.php/cadernobiologicas/article/view/2578/1986

22. Kant I. Fundamentação da metafísica dos costumes. São Paulo: Edições 70; 2007. 117 p.

23. Maffesoli M. Pactos emocionais: reflexões em torno da moral, da ética e da deontologia. Curitiba: PUCPRESS; 2018.80 p.

24. Façanha TRS, Maluf F. A presença do ensino da bioética na enfermagem. Rev Pró-Univer SUS [Internet] 2017 [cited 2020 Jul 13];08(1):17-25. Available from: http://editora.universidadedevassouras.edu.br/index.php/RPU/article/view/866

25. Lima AF, Lopes LCS, Soane AMNC, Fortes AFA. Egressos de enfermagem: potencialidades no processo de formação profissional para inserção no mercado de trabalho. Indagatio Didactica. 2017;9(4):65-80. https://doi.org/10.34624/id.v9i4.715

26. Bristot RB, Ceretta LB, Soratto MT. Conflitos éticos da equipe de enfermagem no processo de trabalho na Atenção Básica. Enferm Bras. 2017;16(1):11-9. https://doi.org/10.33233/eb.v16i1.899

27. Nora CRD, Zoboli ELCP, Vieira MM. Ethical deliberation in health: an integrative literature review. Rev Bioét. 2015;23(1):114-23. https://doi. org/10.1590/1983-80422015231052

28. Nora CRD, Deodato S, Vieira MMS, Zoboli ELCP. Elements and strategies for ethical decision-making in nursing. Texto Contexto Enferm. 2016;25(2):1-9. https://doi.org/10.1590/0104-07072016004500014

29. Paz LG, Kostov B, Pina JAL, Yamoz AZ, Rubio MDN, Almirall AS. Ethical behaviour in clinical practice: a multidimensional Rasch analysis from a survey of primary health care professional of Barcelona (Catalonia, Spain). Qual Life Res. 2014;23(10):2681-91. https://doi.org/10.1007/ s11136-014-0720-x

30. Ulrich CM, Zhou QP, Hanlon A, Danis M, Grady C. The Impact of ethics and work-related factors on nurse practitioners' and physician assistants' views on quality of primary healthcare in the United States. Appl Nurs Research. 2014;27(3):152-56. https://doi.org/10.1016/j. apnr.2014.01.001

31. Vailatti DB, Júnior ABS. A influência do pensamento de Immanuel Kant na construção dos conceitos de ética e de dignidade da pessoa humana. (Re)pensando direito [Internet]. 2018 [cited 2020 Jul 13]; 8(15):03-13. Available from: https://core.ac.uk/download/pdf/229767171.pdf

32. Maffesoli M. O tempo retorna: formas elementares da pós-modernidade. Rio de Janeiro: Forense Universitária; 2012.128 p.

33. Maffesoli M. A ordem das coisas: pensar a pós-modernidade. Rio de Janeiro: Forense; 2016. 276 p.

34. Maffesoli M. Entre o bem e o mal. Lisboa: Instituto Piaget; 2002. 177p. 